\title{
How Effective is Regional Spatial Detail Plans as Instrument of Flood Management (Case Study:Kedurus Watershed,Surabaya City)
}

\author{
Lukman Yusuf, Adjie Pamungkas, and Eko Budi Santoso \\ Department of Urban and Regional Planning, Institut Teknologi Sepuluh Nopember, Surabaya \\ e-mail: ylukman36@gmail.com
}

\begin{abstract}
Abstrak-Surabaya city has detailed spatial planning documents as instruments for flood reduction. The detailed spatial plan for the area regulates land use plans to prevent uncontrolled land use changes that cause flooding. The research question is "What is the efficiency of the detailed spatial plan as an instrument for flood management in the Kedurus River Basin?". The analysis tool is the spatial modeling of floods based on 2D Flow Area using HEC RAS 5 software. The first step is to build a spatial flood model using the existing condition parameters, the next step is to apply the parameters derived from the detailed spatial plan in the Kedurus River Basin on the models that have been built. The result is that the implementation of detailed regional spatial plans in the Kedurus watershed tends not to reduce the area of flood inundation even on the contrary increases the runoff coefficient. In the spatial model of flooding it is known that the condition of the return period of 20 years also shows an increase in the area of flood inundation to 0.5-1 meters from the existing condition which initially covered an area of $45.92 \mathrm{Ha}$ to $72.38 \mathrm{Ha}$.
\end{abstract}

Keywords-RDTRK, Flood, Landuse.

\section{INTRODUCTION}

$\mathrm{F}$ LOOD is a disaster that has a high frequency of occurrence and large losses [1]. Urban flooding is caused by urban development which causes land conversion and results in the reduction of water catchment areas[2][3]. So that the flood inundation area occurs. Spatial planning is a policy that regulates a plot of land use to fit the best function, including as an instrument of flooding. The spatial plan has the ability to be a flood instrument because there are land use plans and basic building coefficient plans in it [4]. land use and building coefficient significantly influence the process of flooding[[4][5][6][7]. Because these 2 things will have an impact on the runoff coefficient or Run Off value [8].

Surabaya City has a flood prone area, Kedurus watershed [4]. When extreme rainfall this region will experience a flood inundation with a depth of up to 1 meter and a pool area of more than $100 \mathrm{Ha}$ [4]. Where Kedurus River Basin is one of the centers of economic development in West Surabaya[[5],[9]]. So we need a strategy to deal with flooding in the Kedurus River Basin.The city of Surabaya already has a detailed spatial plan namely the Regional Spatial Detail Plan or RDTRK. The spatial plan already has legal force through regional regulations. In addition, the spatial plan was used as a consideration for granting a building permit.If the approach used by the spatial plan in the Kedurus River Basin as an instrument for flood reduction, the ideal conditions

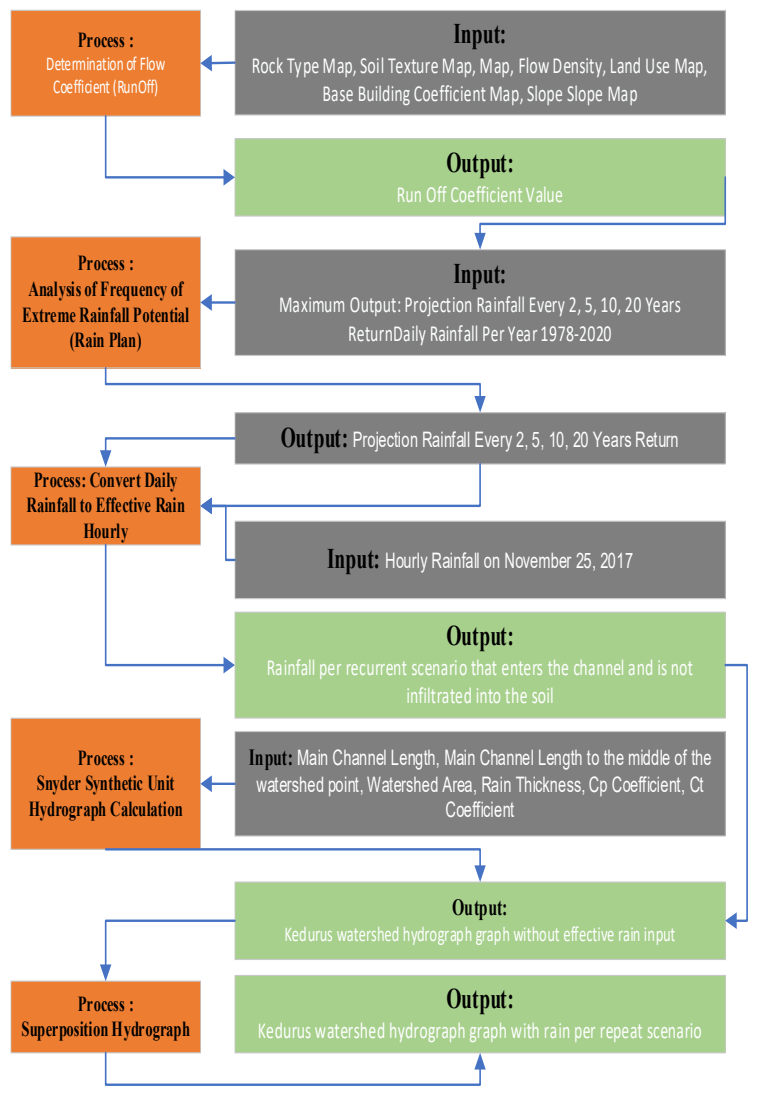

Figure 1. Stage 1 process flow.

expected when the spatial plan is implemented will have an impact on reducing the area of the inundation area[[5][7],[10][11][12]-[13].

So the research question is "How is the performance of the spatial plan in the Kedurus watershed in reducing the size of the flood inundation area?"

\section{METHOD}

The research method used is flood spatial modeling. A spatial model of flood will be built with the help of HEC RAS 2D Flo Area [14][15].Data input needed in this research is

1. Land Use Map 1: 1000

2. Base Building Coefficient Map Exiting 1: 1000

3. Land Use Plan Maps

4. Renacna Map of Building Base Coefficients

5. Terain Digital Map Model 0.33 X 0.33 Meters from Lidar 
The $6^{\text {th }}$ International Seminar on Science and Technology (ISST) 2020

July $25^{\text {th }} 2020$, Institut Teknologi Sepuluh Nopember, Surabaya, Indonesia

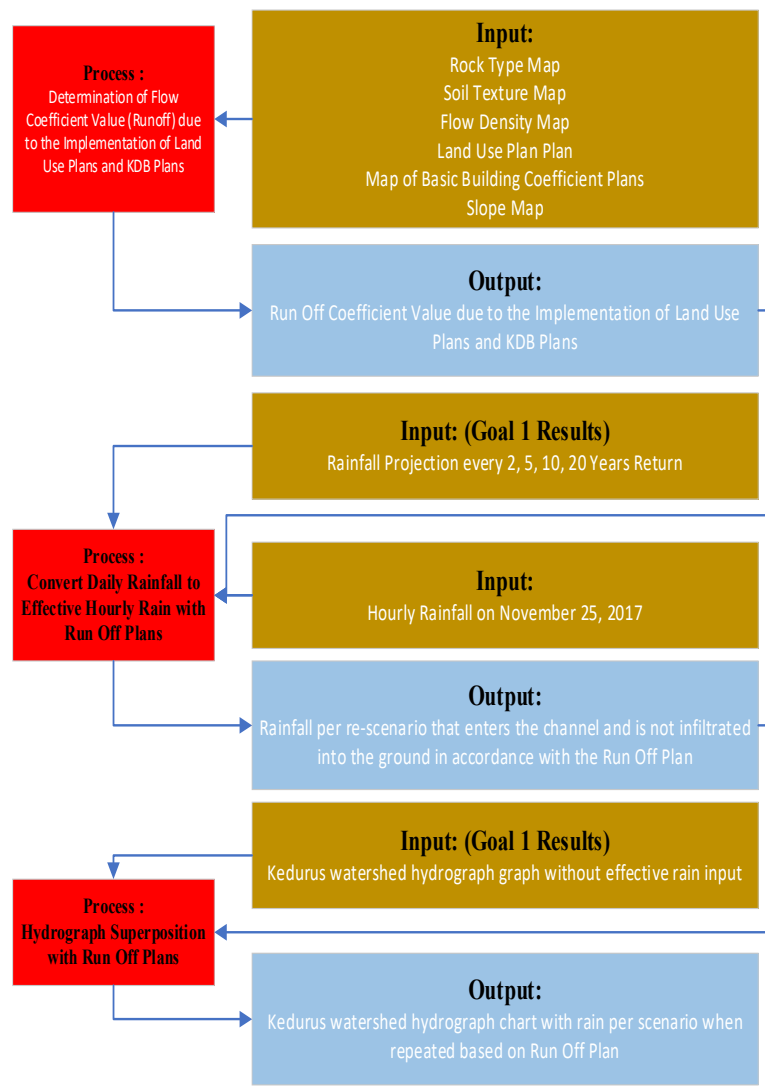

Figure 2. Stage 2 process flow.

6. Maximum Daily Rainfall Per Year 1979-2020

7. Land Type Map

8. Soil Texture Map

9. Channel Density Map

10. Flooding and Depth History Points

The stages of the study were divided into 2 as follows:

\section{A. Stage 1: Existing Condition}

Building spatial models of floods based on existing conditions. The aim is to identify potential maps of flood inundation areas in the use of excavated land and the basic coefficients of existing buildings. In addition, this stage will also validate the flood spatial model that was built. Preparation of spatial flooding models is supplied by identifying runoff coefficient values or Run off areas by overlaying land use maps, land type maps and slope maps. After the run-off value is known then an extreme rainfall projection is calculated which may occur with the LOGNORMAL formula. The following LOG-NORMAL formula is the projection of extreme rainfall.

$$
Y_{T}=\bar{Y} K_{T} S
$$

With information:

YT: Estimated value is expected to occur with a return period $\mathrm{T}$

Y: The average value of the variate count

$\mathrm{S}$ : The standard deviation of the variate value

KT: Frequency factor

Input in this calculation is the maximum daily rainfall per year from 1979 to 2020. Furthermore, it is calculated that the

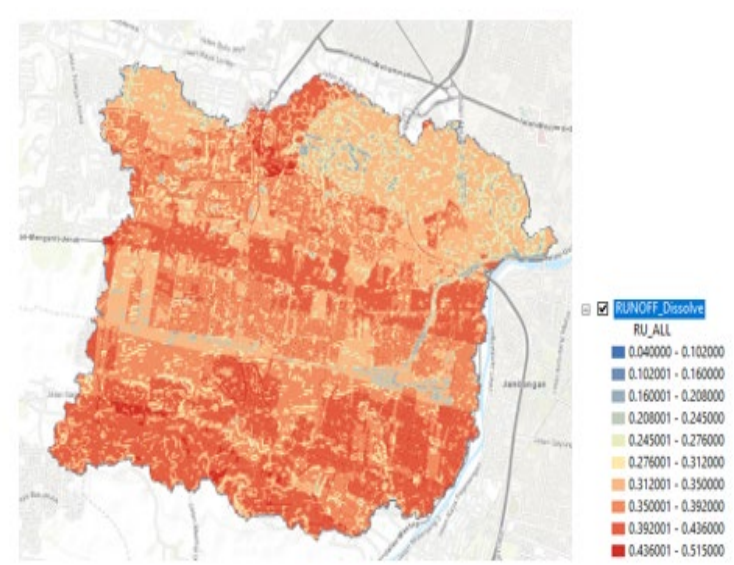

Figure 3. Map calculation of the existing Run Off condition.

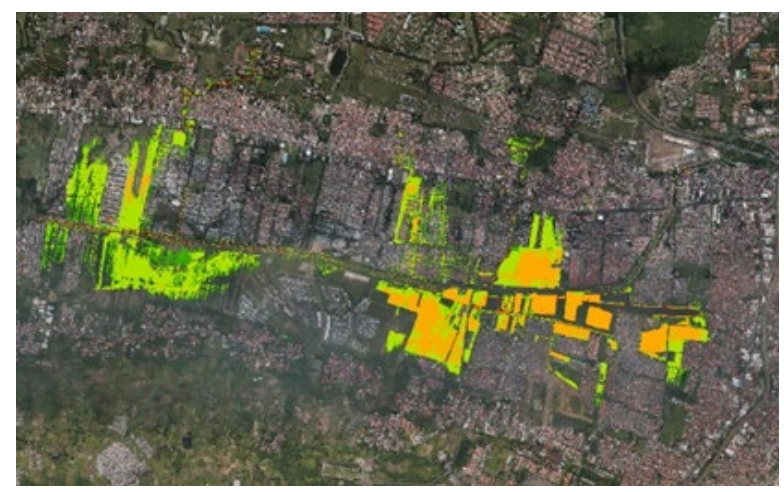

Figure 4. Flood Inundation Map Exising Conditions based on Flood Depth.

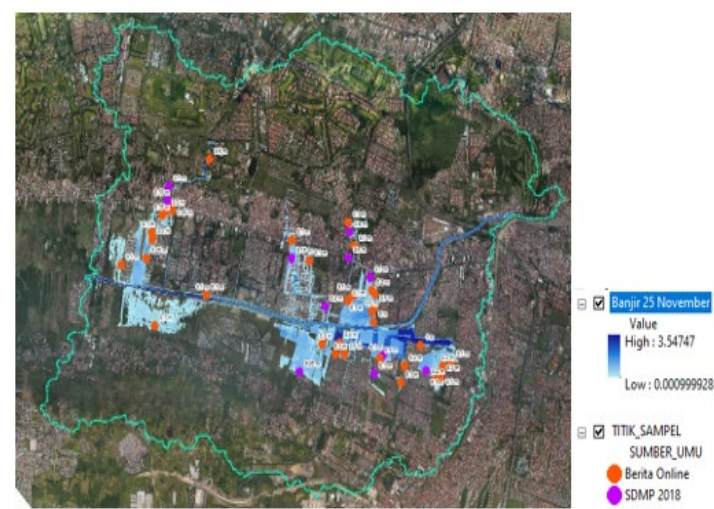

Figure 5. RMSE Model Validation.

rainfall is not absorbed by the land which has the potential to become flooded with the Run off value that has been obtained. Then from that value the peak discharge is calculated using Synder's Synchronous Synthetic Feed. Furthermore, the manning coefficient map is made based on the existing land use map. Synthetic unit hydrographs, manning coefficient maps and topographic maps that have been made are entered in the HEC-RAS software with 2D Flow Area models. This process will produce a map of the potential for inundation in the Kedurus River Basin. The map will be validated with a flood historical field measurement point and a Cross Validation will be performed. Stage 1 process flow can see Figure 1. 
The $6^{\text {th }}$ International Seminar on Science and Technology (ISST) 2020

July $25^{\text {th }} 2020$, Institut Teknologi Sepuluh Nopember, Surabaya, Indonesia

Table 1

Rainfall calculation may not be absorbed into the ground when a return of 20 years in existing conditions

\begin{tabular}{cccc}
\hline \hline NO & Percentage & $\begin{array}{c}\text { Thick Rain } \\
\text { On } \\
\text { 20 years Return } \\
\text { Period }\end{array}$ & $\begin{array}{c}\text { Rain } \\
\text { that } \\
\text { not infiltrated the soil }\end{array}$ \\
\hline t-1 & 11.78 & 16.95 & 0.00 \\
t-2 & 49.74 & 71.59 & 39.59 \\
t-3 & 30.49 & 43.89 & 11.89 \\
t-4 & 6.33 & 9.11 & 0.00 \\
t-5 & 1.05 & 1.52 & 0.00 \\
t-6 & 0.44 & 0.63 & 0.00 \\
t-7 & 0.18 & 0.25 & 0.00 \\
\hline & & 143.94 & 51.48 \\
\hline \hline
\end{tabular}

Table 2 .

Flood Inundation Area Exising Conditions based on Flood Depth

\begin{tabular}{cccc}
\hline \hline \multirow{2}{*}{ Flood Depth } & & \multicolumn{2}{c}{20 Years } \\
& & Ha & $\%$ \\
\hline Low & $0-0.1$ & 42.33 & 1.53 \\
Medium & $0.1-0.5$ & 115.78 & 4.19 \\
High & $0.5-1$ & 67.27 & 2.43 \\
Extrem & $1-1.5$ & 3.50 & 0.13 \\
Total Flood Inundation Area & 228.88 & 8.27 \\
\hline Area of Research & & $2,766.08$ & \\
\hline \hline
\end{tabular}

Table 3.

Rainfall calculation table may not be absorbed into the ground when a 20-year return conditions the plan

\begin{tabular}{|c|c|c|c|}
\hline NO & Percentage & $\begin{array}{c}\text { Thick Rain } \\
\text { On } \\
20 \text { years Return } \\
\text { Period }\end{array}$ & $\begin{array}{c}\text { Rain } \\
\text { that } \\
\text { not infiltrated the soil }\end{array}$ \\
\hline $\mathrm{t}-1$ & 11.78 & 16.95 & 0 \\
\hline $\mathrm{t}-2$ & 49.74 & 71.59 & 41.09 \\
\hline $\mathrm{t}-3$ & 30.49 & 43.89 & 13.39 \\
\hline $\mathrm{t}-4$ & 6.33 & 9.11 & 0 \\
\hline $\mathrm{t}-5$ & 1.05 & 1.52 & 0 \\
\hline $\mathrm{t}-6$ & 0.44 & 0.63 & 0 \\
\hline \multirow[t]{2}{*}{$\mathrm{t}-7$} & 0.18 & 0.25 & 0 \\
\hline & & 143.94 & 54.48 \\
\hline
\end{tabular}

Table 4.

Flood Inundation Area Plan Conditions based on Flood Depth

\begin{tabular}{cccc}
\hline \multirow{2}{*}{ Flood Depth } & \multicolumn{2}{c}{ 20 Years Return Period } \\
& \multicolumn{2}{c}{ Spatial Plan } \\
Ha & $\%$ \\
Low & $0-0.1$ & 42.04 & 1.52 \\
\hline Medium & $0.1-0.5$ & 109.58 & 3.96 \\
High & $0.5-1$ & 72.38 & 2.62 \\
Extrem & $1-1.5$ & 2.40 & 0.09 \\
Area Of Flood Inundation & 226.41 & 8.19 \\
\hline Area of Research & \multicolumn{3}{c}{$2,766.08$} \\
\hline \hline
\end{tabular}

\section{B. Stage 1: Spatial Plan Condition}

After obtaining a valid spatial flood model and an existing flood inundation map. An evaluation of the plan conditions of the spatial plan in the Kedurus watershed was carried out with a spatial flood model that was created. The results will be compared with the existing flood inundation map to see the changes. From the spatial model of floods made in phase 1 , changes will be made to the land use plan data and the basic building coefficient plan. These changes will have an impact to recalculate several modeling stages. The recalculation was

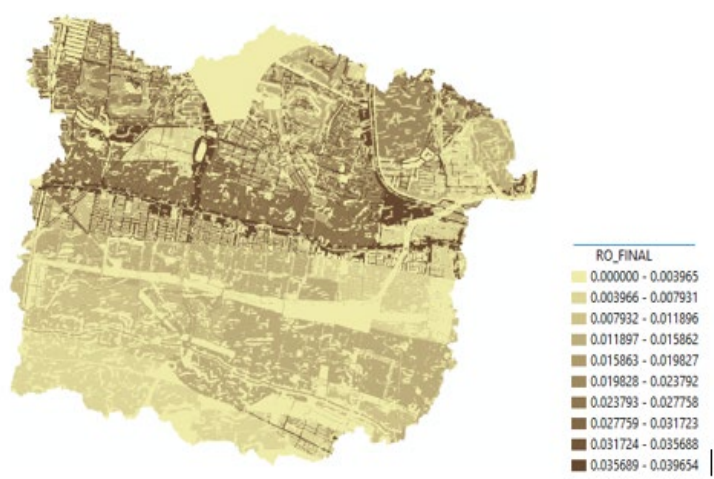

Figure 6. Map calculation of Run Off Plan conditions.

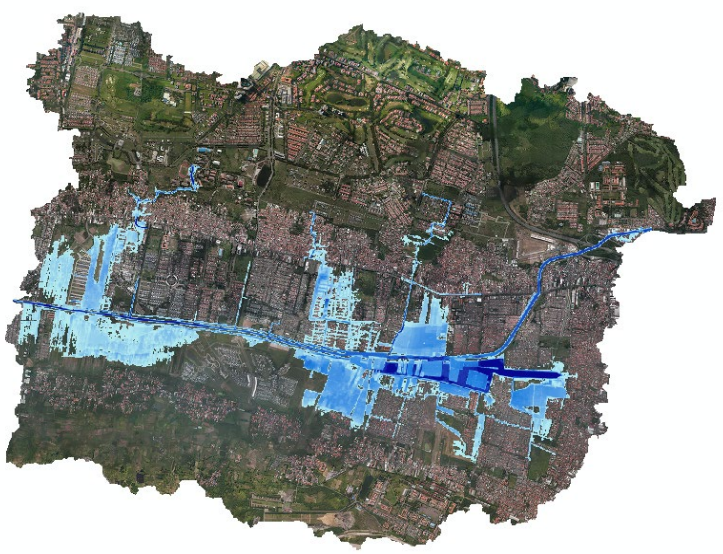

Figure 7. Inundation Flood Plan Conditions.

Table 5.

Comparison table of flood inundation area per class depth of planned and existing conditions

\begin{tabular}{cccccc}
\multicolumn{5}{c}{ and existing conditions } \\
\hline \hline \multirow{2}{*}{ Flood Dept } & \multicolumn{5}{c}{ 20 Years Return Period } \\
& & Existing & \multicolumn{2}{c}{ Plan } \\
& & Ha & \multicolumn{1}{c}{ Ha } & $\%$ \\
\hline Low & $0-0.1$ & 42.01 & 1.52 & 42.04 & 1.52 \\
Medium & $0.1-0.5$ & 115.98 & 4.19 & 109.58 & 3.96 \\
High & $0.5-1$ & 45.92 & 1.66 & 72.38 & 2.62 \\
Extrem & $1-1.5$ & 3.24 & 0.12 & 2.40 & 0.09 \\
Total Flood Inundation Area & 228.88 & 8.27 & 226.41 & 8.19 \\
\hline Area of Research & \multicolumn{5}{c}{$2,766.08$} \\
\hline \hline
\end{tabular}

carried out on the identification of the Run Off value because it changed the existing land use map and the basic coefficient map of the existing building into a land use plan map and a map of the basic building coefficient plan. Changes in the value of run off cause changes in rainfall that are not absorbed into the ground and change the peak discharge. Changes in peak discharge have an impact on the results of different flood inundation maps. After the flood inundation map is obtained at the condition of the plan it will be compared with the results of the flood inundation map at the existing condition. Stage 2 process flow can see Figure 2.

\section{RESULT}

In order to adjust the research stages, the results and discussion will be listed according to the research stages in the research methodology. 
The $6^{\text {th }}$ International Seminar on Science and Technology (ISST) 2020

July $25^{\text {th }} 2020$, Institut Teknologi Sepuluh Nopember, Surabaya, Indonesia

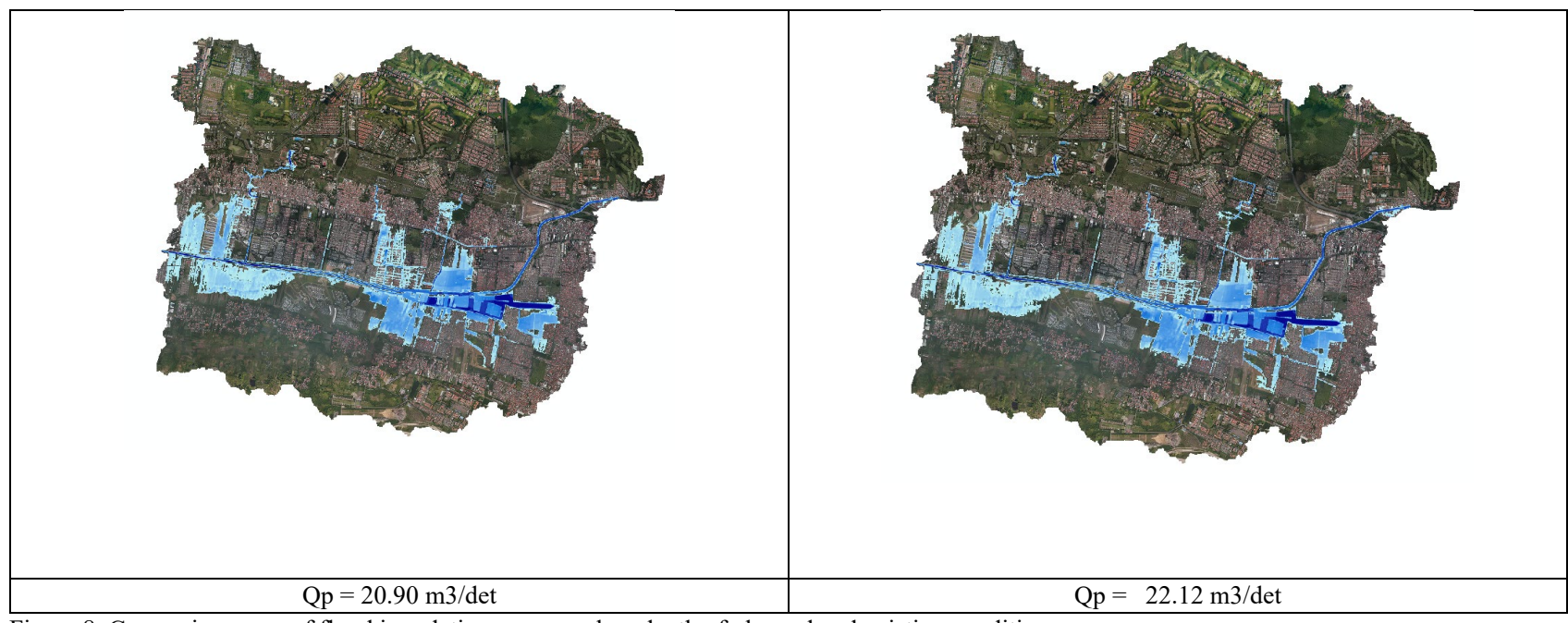

Figure 8. Comparison map of flood inundation area per class depth of planned and existing conditions

\section{A. Stage 1: Existing Condition}

In the first stage of spatial modeling of flooding with the input of existing land use maps and the basic coefficient map of the existing buildings results in a Run Off coefficient of 0.36 . From this value it means that when it rains $36 \%$ of rainfall will not be absorbed into the ground. Map calculation of the existing Run Off condition can see Figure 3.

Then the results of the calculation of rainfall projections at a 20 -year return with the LOG-NORMAL formula produce a rainfall potential of $143.94 \mathrm{~mm} /$ day. Furthermore, the calculation of rainfall that is potentially not absorbed into the ground produces a value of $51.48 \mathrm{~mm} /$ day. Calculation of peak discharge results in exciting conditions showing a value of $20.9 \mathrm{~m} 3$ / sec. Rainfall calculation may not be absorbed into the ground when a return of 20 years in existing conditions can see Table 1.

Then modeling in the HECRAS 2D Flow Area shows that the flood inundation area is 228.88 ha or 8.27 of the Kedurus watershed area. If viewed from the width of the flood depth to low depth (0-0.1 meters) covering an area of $42.33 \mathrm{Ha}$, medium depth (0.1-0.5 meters) covering an area of 115.78 Ha, high depth (0.5-1 meters) covering $67.27 \mathrm{Ha}$, extreme depth (1-1.5 meters ) covering an area of 3.50 Ha. Flood Inundation Area Exising Conditions based on Flood Depth can see Table 2. Flood Inundation Map Exising Conditions based on Flood Depth can see Figure 4.

The results of the model are then validated by cross validation techniques by comparing the points of validation between the results of the 2017 flood inundation map model with flood event data in the Surabaya Drainage Management Plan 2018 Document. The formula for calculating the accuracy value used is RMSE (Root Mean Square Error). The validation point used is 47 points and produces an RMSE value of 0.046 which is considered valid because the value is $<0.1$. RMSE Model Validation can see Figure 5.

\section{B. Stage 2: Spatial Plan Condition}

After obtaining an existing flood inundation map and a valid flood spasil model. Then an evaluation of the conditions of the plan is carried out by entering the map of the land use plan and the map of the basic coefficient of the building in the flood spatial model. Calculation of rainfall Run Off coefficient value plan conditions produce a value of 0.38 , where this has increased from exciting conditions $(0.36)$. This can be interpreted that the condition of the plan even increases the potential for flooding. Map calculation of Run Off Plan conditions can see Figure 6.

In addition, the calculation of rainfall that is potentially not absorbed into the ground shows a value of $54.48 \mathrm{~mm} /$ day, the value has increased from the existing condition (51.48 $\mathrm{mm} /$ day). The calculation of peak discharge also experienced the same conditions, showing a value of 22.12 $\mathrm{m} 3$ / second, an increase from the existing condition ( $20.9 \mathrm{~m} 3$ / second). Rainfall calculation table may not be absorbed into the ground when a 20 -year return conditions the plan can see Table 3.

Spatial modeling of flooding with HECRAS 2D Flow Area under the plan shows the flood inundation area of $226.41 \mathrm{Ha}$ has decreased from existing conditions (228.88 ha). If viewed from the depth of the flood depth in the planned conditions for low depth (0-0.1 meters) covering an area of $42.04 \mathrm{Ha}$, moderate depth (0.1-0.5 meters) covering $109.58 \mathrm{Ha}$, high depth (0.5-1 meters) covering $72.38 \mathrm{Ha}$, extreme depth (1 1.5 meters) area of $2.40 \mathrm{Ha}$. Flood inundation area plan conditions based on flood depth can see Table 4 and Inundation flood plan conditions can see Figure 7.

When compared between the results of spatial modeling of flooding between existing conditions and the condition of the plan, the total inundation has indeed decreased from 228.88 Ha (exciting) to $226.41 \mathrm{Ha}$ (Plan). However, when viewed from the flood depth class at the high depth class (0.5-1 meter), there has been an increase from $45.92 \mathrm{Ha}$ (existing) to $72.38 \mathrm{Ha}$ (planned). Comparison table of flood inundation area per class depth of planned and existing conditions can see Table 5 and Comparison map of flood inundation area per class depth of planned and existing conditions can see Figure 8.

So from these conditions it can be concluded that the performance of the spatial plan in the Kedurus watershed is not effective enough in reducing the area of flood inundation. it even tends to increase the potential 
The $6^{\text {th }}$ International Seminar on Science and Technology (ISST) 2020

July $25^{\text {th }} 2020$, Institut Teknologi Sepuluh Nopember, Surabaya, Indonesia

\section{CONCLUSION}

Based on the results and discussion, it is known that the Kedurus watershed exciting condition has a Run Off coefficient of 0.36 with the peak discharge of the watershed on a 20 year return period of $20.90 \mathrm{~m} 3 / \mathrm{sec}$. The results of flood modeling show that the potential for inundation area at the 20 year return period is $228.88 \mathrm{Ha}$. Whereas if the condition of the plan (land use plan, basic building coefficient plan and the planned drain capacity) produces a Runoff coefficient of 0.38 with a peak discharge during a 20 year return period of $22.12 \mathrm{~m} 3 / \mathrm{sec}$. The results of the modeling in the condition of the plan show that the area of inundation at the 20th time was $228.88 \mathrm{Ha}$, decreased from $226.41 \mathrm{Ha}$ in the existing condition. So that the existing land use plan, the basic building coefficient plan and the existing drainage plan do not reduce the potential for flooding, it tends to increase the potential for flooding.

\section{REFERENCES}

[1] A. F. Aryanto, "Pengaruh Perubahan Penutup Lahan Terhadap Debit Aliran Permukaan di Sub-Das Keduang Kabupaten Wonogiri," UNS (Sebelas Maret University), 2010.

[2] X. Yang, H. Chen, Y. Wang, and C. Y. Xu, "Evaluation of the effect of land use/cover change on flood characteristics using an integrated approach coupling land and flood analysis," Hydrol. Res., vol. 47, no. 6, pp. 1161-1171, 2016, doi: 10.2166/nh.2016.108.

[3] Y. Gao, J. Chen, H. Luo, and H. Wang, "Prediction of hydrological responses to land use change," Sci. Total Environ., vol. 708, no. 1, p. 134998, 2020, doi: 10.1016/j.scitotenv.2019.134998.

[4] S. Purwitaningsih and A. Pamungkas, "Analisis Kondisi Hidrologi Daerah Aliran Sungai Kedurus untuk Mengurangi Banjir Menggunakan Model Hidrologi SWAT," J. Tek. ITS, vol. 6, no. 2, pp. 107-111, 2017, doi: 10.12962/j23373539.v6i2.24809.

[5] M. Starzec, J. Dziopak, and D. Słyś, "An analysis of stormwater management variants in urban catchments," Resources, vol. 9, no. 2, pp. 1-17, 2020, doi: 10.3390/resources9020019.

[6] C. H., Wizor and W. Elekwachi, "Geo-spatial analysis of urban wetlands loss in obio/akpor local government area of rivers state, nigeria," Asian J. Geogr. Res., vol. 3, no. 1, pp. 35-48, 2020, doi: 10.9734/ajgr/2020/v3i130099.

[7] S. N. Suri, C. Johnson, B. Lipietz, and E. Al., "Words into action guidelines: Implementation guide for land use and urban planning," Flood Resilience Portal. United Nations Office for Disaster Risk Reduction, 2020, [Online]. Available: http://repo.floodalliance.net/jspui/handle/44111/3364.

[8] F. da Silva Peixoto, I. N. Cavalcante, and D. F. Gomes, "Influence of land use and sanitation issues on water quality of an urban aquifer," Water Resour. Manag., vol. 34, no. 2, pp. 653-674, 2020, doi: 10.1007/s11269-019-02467-6.

[9] I. Sumiati and T. Firdausijah., "Kajian Strategis Kebijakan Satu Peta (One Map Policy) Bidang Perencanaan Tata Ruang," in Seminar Nasional Administrasi Publik Dinamika Perkembangan Administrasi Publik di Era Disrupsi dan Tantangan Global, 2019, pp. 258-274, [Online]. Available: http://repository.unpas.ac.id/42143/.

[10] A. Chalid and B. Prasetya, "Utilization of a pond in East Jakarta for a sustainable urban drainage system model," IOP Conf. Ser. Earth Environ. Sci., vol. 437, no. 1, pp. 1-10, 2020, doi: 10.1088/17551315/437/1/012018.

[11] A. Kallioras, "Urban Flood Hazard Management - Case Study: Shanghai," Delft University of Technology, Shanghai, 2020.

[12] A. Pamungkas and S. Purwitaningsih, "Green and grey infrastructures approaches in flood reduction," Int. J. Disaster Resil. Built Environ., vol. 10 , no. 5, pp. 343-362, 2019, doi: 10.1108/IJDRBE-03-20190010 .

[13] A. Pamungkas and S. Purwaningsih, "A Combination of Green and Grey Infrastructures Approaches in Flood Reduction: Kedurus Case Study, Indonesia," in International Conference on Disaster Management, Universitas Andalas, Padang,2018.

[14] S. Grimaldi, A. Petroselli, E. Arcangeletti, and F. Nardi, "Flood mapping in ungauged basins using fully continuous hydrologichydraulic modeling," J. Hydrol., vol. 487, pp. 39-47, 2013, doi: 10.1016/j.jhydrol.2013.02.023.

[15] USACE, HEC-RAS River Analysis System, Application Guide, Version 5.0, February 2016. U.S. Army Cormps of Engineers. USA: Institute of Water Resources, Hydrological Engineering Center Davis., 2016. 